University of Nebraska - Lincoln

DigitalCommons@University of Nebraska - Lincoln

Faculty Publications, Department of Psychology

Psychology, Department of

2009

\title{
Gene-Environment Interactions across Development: Exploring DRD2 Genotype and Prenatal Smoking Effects on Self-Regulation
}

\author{
Sandra A. Wiebe \\ University of Nebraska-Lincoln, sandra.wiebe@ualberta.ca \\ Kimberly Andrews Espy \\ University of Nebraska-Lincoln, kespy2@unl.edu \\ Christian Stopp \\ University of Nebraska-Lincoln \\ Jennifer Respass \\ University of Nebraska-Lincoln \\ Peter Stewart \\ University of Nebraska-Lincoln, pstewart3@unl.edu
}

See next page for additional authors

Follow this and additional works at: https://digitalcommons.unl.edu/psychfacpub

Part of the Psychiatry and Psychology Commons

Wiebe, Sandra A.; Espy, Kimberly Andrews; Stopp, Christian; Respass, Jennifer; Stewart, Peter; Jameson, Travis R.; Gilbert, David G.; and Huggenvik, Jodi I., "Gene-Environment Interactions across Development: Exploring DRD2 Genotype and Prenatal Smoking Effects on Self-Regulation" (2009). Faculty Publications, Department of Psychology. 368.

https://digitalcommons.unl.edu/psychfacpub/368

This Article is brought to you for free and open access by the Psychology, Department of at DigitalCommons@University of Nebraska - Lincoln. It has been accepted for inclusion in Faculty Publications, Department of Psychology by an authorized administrator of DigitalCommons@University of Nebraska - Lincoln. 


\section{Authors}

Sandra A. Wiebe, Kimberly Andrews Espy, Christian Stopp, Jennifer Respass, Peter Stewart, Travis R. Jameson, David G. Gilbert, and Jodi I. Huggenvik 


\title{
Gene-Environment Interactions across Development: Exploring DRD2 Genotype and Prenatal Smoking Effects on Self-Regulation
}

\author{
Sandra A. Wiebe, ${ }^{a}$ Kimberly Andrews Espy, ${ }^{\text {a }}$ Christian Stopp, ${ }^{\mathrm{b}}$ Jennifer Respass, ${ }^{\mathrm{b}}$ \\ Peter Stewart, ${ }^{b}$ Travis R. Jameson, ${ }^{c}$ David G. Gilbert, ${ }^{\mathrm{d}}$ and Jodi I. Huggenvik ${ }^{\mathrm{c}}$
}

a) Department of Psychology, University of Nebraska-Lincoln; b) Office of Research, University of Nebraska-Lincoln; c) Department of Physiology, Southern Illinois University; d) Department of Psychology, Southern Illinois University

Corresponding author - Sandra A. Wiebe, Department of Psychology, Room 102, 501 Building,

University of Nebraska-Lincoln, Lincoln, NE 68588-0206; email swiebe2@unl.edu

\begin{abstract}
Genetic factors dynamically interact with both pre- and postnatal environmental influences to shape development. Considerable attention has been devoted to gene-environment interactions $(\mathrm{G} \times \mathrm{E})$ on important outcomes (A. Caspi \& T. E. Moffitt, 2006). It is also important to consider the possibility that these $\mathrm{G} \times \mathrm{E}$ effects may vary across development, particularly for constructs like self-regulation that emerge slowly, depend on brain regions that change qualitatively in different developmental periods, and thus may be manifested differently. To illustrate one approach to exploring such developmental patterns, the relation between variation in the TaqIA polymorphism, related to D2 dopamine receptor expression and availability, and prenatal exposure to tobacco was examined in two exploratory studies. First, in 4-week-old neonates, genotype-exposure interactions were observed for attention and irritable reactivity, but not for stress dysregulation. Second, in preschool children, genotype was related to Preschool Trail Making Test (K. A. Espy and M. F. Cwik, 2004) task performance on conditions requiring executive control; children with both the A1+ genotype and a history of prenatal tobacco exposure displayed disproportionately poor performance. Despite study limitations, these results illustrate the importance of examining the interplay between genetic and prenatal environmental factors across development.
\end{abstract}

Keywords: gene-environment interactions, prenatal smoking, dopamine receptor genes, self-regulation

Developmental scientists (e.g., Bronfenbrenner \& Ceci, 1994) have long emphasized that genetic and environmental influences mutually and dynamically interact to produce observable phenotypes. Only recently has it become possible to identify specific examples of gene-environment $(\mathrm{G} \times \mathrm{E})$ interactions that are relevant to human psychological processes, typically by using the candidate gene approach (Caspi \& Moffitt, 2006). Candidate gene designs involve the comparison of groups of individuals with different alleles or forms of a gene. In a landmark study, Caspi et al. (2002) found that individuals who had the monoamine oxidase A (MAOA) allele associated with higher activity and who had experienced substantial trauma in childhood were more likely to exhibit antisocial behavior. Since that landmark study, this $G \times E$ interaction has been replicated in several independent samples (e.g., Ducci et al., 2008; Widom \& Brzustowicz, 2006) and has been extended to other outcomes, such as depression (Cicchetti, Rogosch, \& Sturge-Apple, 2007). G $\times$ E candidate gene studies have had a substantial impact in psychiatry in general and child psychiatry in particular, given the strong heritability of, and phenotypic variation within, many disorders. For example, the relation between insensitive parenting and externalizing behaviors in preschoolers varies by child genotype for the $D_{4}$ dopamine receptor (DRD4; Bakermans-Kranenburg \& van Ijzendoorn, 2006). Only in preschool children with the DRD4 exon III 7-repeat allele was insensitive parenting associated with more frequent externalizing behaviors.

Much work has been devoted to identifying continuity in key behaviors across developmental periods (Côté, Tremblay, \& Nagin, 2002; Hill, Degnan, Calkins, \& Keane, 2006). However, only a subset of children display such stability (Moffitt, 1993). It has been shown, for example, that the inattentive symptomatology that is central to a diagnosis of attention-deficit/hyperactivity disorder (ADHD) is not prominent in preschoolers, and for many children it manifests suddenly at school age (Lavigne et al., 1998). Most adolescents "outgrow" hyperactivity and do not display such behaviors as adults (Mannuzza, Klein, Bessler, Malloy, \& LaPadula, 1998). Although this different pattern is related in part to different agebased expectations for behavior (Wakschlag et al., 2007), little consideration has been given thus far to the possibility that interactive effects of genetics and the environment may vary across developmental periods.

One environmental influence is maternal use of psychoactive substances during pregnancy. Smoking, drinking, and the use of illegal and prescription drugs during pregnancy funda-

Portions of these data were presented at the meetings of the Society for Neuroscience in Atlanta, 2006, and the International Society on Infant Studies in Vancouver, 2008. This research was supported by National Institutes of Health Grants R01 MH065668 and R01 DA014661.

We thank Alison Brindle, Mary Cwik, Jessica Eidem, Lisa Hoane, Abigail Johnson, Besiana Liti, Jessica Martin, and other members of the Developmental Cognitive Neuroscience Laboratory for assistance with data collection, and the families who participated in this research. 
mentally alter the environment in which the fetus develops. Prenatal smoking, in particular, is associated with increased risk of childhood self-regulatory disorders (see Linnet et al., 2003, for a review), and there is some evidence that this risk may vary as a function of genetic factors. Neuman et al. (2007) found that among children whose mothers reported cigarette smoking during pregnancy, the risk for diagnosis of ADHD was highest in children with both the $\mathrm{D}_{4}$ dopamine receptor (DRD4) 7-repeat allele and the 3' variable number of tandem repeats 440 allele of the dopamine transporter (DAT1). Two other recent studies have identified $\mathrm{G} \times \mathrm{E}$ interactions involving the DAT1 candidate gene and prenatal tobacco exposure (PTE) in the etiology of externalizing behaviors (Becker, El-Faddagh, Schmidt, Esser, \& Laucht, 2008; Kahn, Khoury, Nichols, \& Lanphear, 2003). Self-regulatory abilities are strongly implicated in ADHD (Nigg, 2005) and have a protracted course of development (Welsh, Pennington, \& Groisser, 1991). On the basis of primate models, it has long been known that the effects of lesions to the neural substrates of self-regulation differ depending on age (Goldman \& Alexander, 1977). As such, examining the interactive effects of dopamine genotype and PTE at different points in development may be particularly fruitful in uncovering such patterns. We discuss the construct of self-regulation, its development, and the separate influences of PTE and another candidate gene involved in dopaminergic neurotransmission, the $\mathrm{D}_{2}$ dopamine receptor (DRD2). We then explore the effects of DRD2 genotype and PTE on self-regulation at two very different developmental periods, the neonatal and preschool, to illustrate the potential utility of this approach.

\section{The Development of Self-Regulation}

Self-regulation is broadly defined to encompass executive control of both cognition and emotion and their joint effect on observed everyday behavior (e.g., temperament constructs of effortful control; Posner \& Rothbart, 2007). Discrete executive control abilities (Stins, van Baal, Polderman, Verhulst, \& Boomsma, 2004), as well as the everyday control of behavior (Yamagata et al., 2005), have a substantial heritable component. A growing literature links self-regulatory abilities and specific candidate genes involved in dopaminergic neurotransmission (e.g., Bishop, Cohen, Fossella, Casey, \& Farah, 2006; Diamond, Briand, Fossella, \& Gehlbach, 2004). The social environment plays a key role in shaping the child's everyday self-regulatory abilities (Calkins, Smith, Gill, \& Johnson, 1998; Wachs, 2006) and executive control abilities (K. G. Noble, Norman, \& Farah, 2005).

The development of self-regulation in the transition from infancy to early childhood is characterized by a shift from exogenous to endogenous control of behavior. In early infancy, neonatal behavior is largely driven by environmental stimuli. External stimuli capture the neonate's attention and elicit a biologically prepotent response, such as orientation or reflexive movements (Riese, 1984; Ruff \& Rothbart, 1996). Furthermore, reactivity to aversive events is considered a stable, temperamental individual difference and is thought to be driven largely by factors like sensory thresholds rather than by active control of emotion (Rothbart, Derryberry, \& Hershey, 2000). In this period, the caregiver plays a critical role in regulating the infant's responses by meeting the infant's needs and soothing the infant (Kopp, 1989). In contrast, preschool children are ca- pable of rudimentary agency and volitional action in the environment, although self-regulatory skill development is by no means complete (Carlson, 2005; Espy, Kaufmann, Glisky, \& McDiarmid, 2001; Prevor \& Diamond, 2005).

Prefrontal structures are strongly implicated in self-regulatory processes, including executive control of cognition (e.g., Duncan \& Owen, 2000) and emotion (Bishop, Duncan, Brett, \& Lawrence, 2004; Ochsner \& Gross, 2005). E. Miller and Cohen (2001) have proposed a model of executive control that emphasizes the prefrontal cortex's modulation of activity in other brain regions through bias signals that boost activation of task-relevant neural pathways. Dopamine neurons originating in midbrain likely play an important role in this process (Montague, Hyman, \& Cohen, 2004) through mesolimbic and mesocortical pathways.

\section{Self-Regulation and the D2 Dopamine Receptor}

DRD2 is primarily expressed in the striatum, nucleus accumbens, and midbrain (Sealfon \& Olanow, 2000). The TaqIA polymorphism is located $10 \mathrm{kB} 3$ to the final exon of the DRD2 gene itself. Two alleles are present, commonly referred to as A1 and A2. The A1 allele is less frequent in most populations, and its frequency varies considerably across ethnic groups (Barr \& Kidd, 1993). Neville, Johnstone, and Walton (2004) recently determined that the TaqIA polymorphism is in fact located within the coding region of a kinase gene that they named ankyrin repeat and kinase domain containing 1 (ANKK1). The specific function of this gene is as yet unknown, but Neville et al. determined that it was expressed in the placenta and spinal cord during prenatal development. As such, associations between the TaqIA polymorphism and variation in DRD2 receptor expression or behavior are most likely due to linkage disequilibrium with an as yet undetermined functional variation in the DRD2 gene (see Fossella, Green, \& Fan, 2006, for a discussion).

Although the mechanism is not understood, there is a substantial body of work linking this polymorphism with meaningful variation in human neuroanatomy and behavior. Presence of the A1 allele (in the homozygous A1A1 genotype or the heterozygous A1A2 genotype, referred to collectively as the A1+ genotype) is related to decreased DRD2 receptor expression and availability in the striatum (Jönsson et al., 1999; E. P. Noble, Blum, Ritchie, Montgomery, \& Sheridan, 1991; Pohjalainen et al., 1998; Thompson et al., 1997) relative to the homozygous A2A2 (A1-) genotype. Not all laboratories have reported this association (e.g., Laruelle, Gelernter, \& Innis, 1998), which is perhaps related to sampling differences (E. P. Noble, 2003). The DRD2 receptor is implicated in executive control, the ability to adapt behavior to changing contingencies (Fossella et al., 2006; Rodríguez-Jiménez et al., 2006; Roesch-Ely et al., 2005), and risk for ADHD (Nyman et al., 2007). Notably, Fossella et al. (2006) found that A1- subjects showed increased anterior cingulate activation during conflict processing.

The TaqIA polymorphism was one of the first identified genetic markers related to human behavior, where the A1+ genotype was associated with higher risk for addiction to nicotine, alcohol, and illegal substances (Blum et al., 1990; Munafò, Clark, Johnstone, Murphy, \& Walton, 2004; Persico, Bird, Gabbay, \& Uhl, 1996). Individuals with the A1+ genotype may derive more cognitive benefit from nicotine (Gilbert et al., 2005), 
experience stronger cravings in response to smoking-related cues (Erblich, Lerman, Self, Diaz, \& Bovbjerg, 2005), and respond poorly to bupropion treatment for smoking cessation (David et al., 2007). However, there remains considerable uncertainty regarding its role in addiction, as the relation to outcome has not been replicated consistently (e.g., Anghelescu et al., 2001). More recently, the A1+ genotype has been associated with "novelty-seeking" personality characteristics (Berman, Ozkaragoz, Young, \& Noble, 2002) and increased sensitivity to reward (Cohen, Young, Baek, Kessler, \& Ranganath, 2005), consistent with fMRI evidence supporting the key role of dopamine circuits in the striatum and prefrontal cortex in processing of both reward (e.g., Berke \& Hyman, 2000; Delgado, Locke, Stenger, \& Fiez, 2003) and novelty (Berns, Cohen, \& Mintun, 1997).

\section{Self-Regulation and PTE}

There is increasing evidence that PTE is associated with self-regulatory deficits. Infants and children whose mothers smoked during pregnancy demonstrate attention problems (Noland et al., 2005; Willoughby, Greenberg, Blair, \& Stifter, 2007) and elevated externalizing behaviors (Day, Richardson, Goldschmidt, \& Cornelius, 2000; Wakschlag, Leventhal, Pine, Pickett, \& Carter, 2006). Furthermore, PTE is associated with increased risk for the clinical diagnosis for conduct disorder (Wakschlag, Pickett, Cook, Beno-witz, \& Leventhal, 2002) and ADHD (Linnet et al., 2003). Furthermore, PTE is associated with low birth weight and perinatal complications (D. Miller, Villa, Hogue, \& Sivapathasundaram, 2001; Nelson, Jodscheit, \& Guo, 1999; U.S. Department of Health and Human Services, 1980), which independently contribute to the risk for ADHD (Nigg \& Breslau, 2007; Szatmari, Saigal, Rosenbaum, Campbell, \& King, 1990). Inconsistent PTE-related differences across development and failures to replicate are not uncommon (e.g., Fried \& Watkinson, 1988; Gaultney, Gingras, Marton, \& DeBrule, 2005). However, many studies have used self-reported smoking and retrospective recall and are underpowered to detect moderate effect sizes (Linnet et al., 2003).

Nonhuman animal models have yielded critical information useful for disentangling effects of nicotine exposure on the developing brain. Briefly, nicotine acts directly on the developing nervous system through activation of nicotinic acetylcholine receptors, which play a critical role in developmental cell signaling (Navarro et al., 1989), including developing dopaminergic circuits (Azam, Chen, \& Leslie, 2007). Premature activation of nicotinic acetylcholine receptors alters the timing of neuronal replication and differentiation, thereby fundamentally changing the structure of the prenatally exposed brain in adulthood (McFarland, Seidler, \& Slotkin, 1991). The impact of PTE is not limited to the cholinergic system, in part because dopaminergic neurons in the striatum receive direct nicotinic input (Lichtensteiger et al., 1982). Nicotine exposure during brain development produces long-term changes in the activity of neural circuits dependent on dopamine (Muneoka et al., 1997), in part mediated by down regulation of $D_{2}$ dopamine receptors in the striatum (Fung \& Lau, 1989; Richardson \& Tiz- abi, 1994). Rats exposed to nicotine prenatally display behavioral abnormalities analogous to deficits identified in humans, including reduced novelty-seeking behavior (Vaglenova, Birru, Pandiella, \& Breese, 2004) and learning and memory deficits (Levin, Wilkerson, Jones, Christopher, \& Briggs, 1996).

Given that both PTE and TaqI A1+ genotype are associated with deficits in dopaminergic function and corresponding difficulties in self-regulation, a natural question, then, is how these two risk factors interact to influence outcomes at different points in development. We used two existing datasets to explore this issue. Self-regulatory behavior was assessed at two distinctly different periods of development: very early infancy, in a sample of prospectively enrolled 1-month-old neonates; and preschool, in a sample of 3- to 6-year-old children. In preschool children, the endogenous control of behavior is rapidly developing (Espy, 2004), supported by rapid changes in prefrontal system structure and function (Giedd et al., 1999; Thatcher, 1994). In contrast, neonatal behavior is driven largely by reactivity to exogenous stimuli, supported by earlier maturing primary sensory brain areas. Contrasting the $\mathrm{G} \times \mathrm{E}$ effects of PTE and TaqIA in these two periods, then, might be particularly illuminating.

\section{Study 1: Neonatal Self-Regulation}

The effects of TaqIA genotype and PTE on self-regulation very early in life were examined in an at-risk sample of neonates. In this study, PTE had been assessed during pregnancy, including biochemical verification of self-reported smoking, and neonates were genotyped on the TaqIA polymorphism. Attention, reactivity, and regulatory behaviors were assessed when neonates were approximately 4 weeks old.

\section{Method}

Participants.A sample of 98 healthy neonates was included in this study. Their mothers were enrolled in the study before the 28th week of pregnancy, with the majority (84\%) recruited around the 16th week. Neonatal self-regulatory behavior was assessed when infants were approximately 4 weeks of age $(M=4.15$ weeks; range $=3.0$ to 5.14$)$. Mothers and neonates were participants in a larger ongoing project examining the sequelae of PTE, and as such, smoking women were oversampled to make up approximately $50 \%$ of the sample. Neonates were included in the present analysis if the 4-week assessment and genotyping were completed. All infants were of White European background. ${ }^{1}$ Infants with atypical illnesses or birth complications known to affect developmental outcomes (e.g., neonatal seizures), preterm delivery before 37 weeks, prenatal exposure to illicit drugs, and those whose mothers reported drinking more than two alcoholic drinks per occasion before pregnancy detection were excluded from participation. Most women in the sample $(75 \%)$ reported some alcohol consumption around their last menstrual period before becoming pregnant. Of women who drank alcohol, nearly all (91\%) reported termination of alcohol use by the 16th week of pregnancy. Furthermore, the amount of alcohol use in those

\footnotetext{
${ }^{1}$ Because the frequency of the A1 allele varies substantially by ethnicity (Barr \& Kidd, 1993), it has been recommended that analyses of the TaqIA allele be conducted separately within subgroups of individuals of homogeneous backgrounds. The ethnicity of the local catchment area where both studies were conducted is predominantly White European, and there were not enough participants of other backgrounds in either Study 1 or Study 2 to permit analysis of subgroups. Therefore, only infants and children of White European background were included in both Studies 1 and 2.
} 
who reported it was no more than one drink at a sitting in the remaining 5 months of pregnancy for all but 2 women. Sample demographic information is provided in Table 1. As expected, maternally reported and biochemical indicators of tobacco exposure differed between tobacco-exposed and nonexposed infants. There was also a small but significant difference in education between tobacco-exposed and nonexposed groups and a difference in birth weight and sex distribution between genotype groups.

Procedures. PTE was assessed prospectively via standardized interview at 14 and 28 weeks' gestation by a research staff member in a private office within the research laboratory. Women reported their average and maximum daily smoking during each month of pregnancy, using trimester information and pregnancy landmarks (Day \& Robles, 1989). Because self-reported prenatal tobacco use may underestimate true use (Bardy, Kataja, \& Pikkarainen, 1993), maternal urine samples were collected at each interview to provide biochemical verification via analysis of cotinine levels using the DRI cotinine assay (Microgenics Corp., Fremont, CA). Cotinine is a byproduct of nicotine, and urinalysis was conducted by U.S. Drug Testing Laboratories (Des Plaines, IL). Women were also interviewed about their health and behavior, including use of alcohol and prescription medications.

Within 12 to $48 \mathrm{hr}$ of infants' delivery, women completed the final standardized interview to report last trimester smoking, and a meconium sample was collected from the baby's diaper. Meconium cotinine levels index nicotine exposure in the last 20 to 24 weeks of pregnancy and were analyzed by U.S.
Drug Testing Laboratories (Des Plaines, IL). Buccal samples for subsequent genotyping were taken from the infant using Catch-All sample collection swabs (Epicentre Biotechnologies, Madison, WI). The Taq DNA polymerase (Invitrogen, Carlsbad, CA) and primers 5'-GTCTAAATTTCCATCTCCGGCTC$3^{\prime}$ and 5'-GGCAAATACCTGATCTGCAAG-3' were used to amplify DRD2-specific sequences by polymerase chain reactions. TaqIA restriction-length polymorphisms were assessed as described by Spitz et al. (1998). The observed allele frequencies did not differ from Hardy-Weinberg equilibrium, $\chi^{2}(1, N$ $=98)=0.03, p=.86$.

When neonates were approximately 4 weeks of age, the Neonatal Temperament Assessment (NTA; Riese, 1983) was administered in the infant's home. This measure was chosen because of its demonstrated sensitivity to neuropsychological deficits related to prenatal substance exposure (Riese, 1989) and later outcome (Matheny, Riese, \& Wilson, 1985; Riese, 1987). One research staff member interviewed the mother about her infant's postnatal tobacco exposure and other health issues, while another staff member who was blind to the infant's prenatal exposure group administered the NTA in a separate room. Assessments were conducted approximately 3060 min after feeding. A brief overview of the NTA is provided here, and a more detailed description is available in Espy, Stopp, Wiebe, Clayton, and Respass (2008). NTA items were administered in several modules: attention-orientation, stress reactivity, soothability, elicitation of reflexes, and summary ratings of infant behavior and state at set points throughout the assessment. Infant orientation to auditory (e.g., bell), visual (e.g., bulls-eye) and auditory-visual stimuli (e.g., face and

Table 1. Sample Demographics and Measures of Tobacco Exposure, by TaqIA Genotype and Prenatal Tobacco Exposure Group

\begin{tabular}{|c|c|c|c|c|c|c|c|c|}
\hline \multirow[b]{3}{*}{ Demographic variable } & \multicolumn{4}{|c|}{ A1 Carriers (A1A1 $n=4 ;$ A1A2 $n=33$ ) } & \multicolumn{4}{|c|}{ A1 Noncarriers $(n=61)$} \\
\hline & \multicolumn{2}{|c|}{$\begin{array}{l}\text { Tobacco-exposed } \\
\qquad(n=15)\end{array}$} & \multicolumn{2}{|c|}{$\begin{array}{l}\text { Nonexposed } \\
\quad(n=22)\end{array}$} & \multicolumn{2}{|c|}{$\begin{array}{l}\text { Tobacco-exposed } \\
\qquad(n=27)\end{array}$} & \multicolumn{2}{|c|}{$\begin{array}{l}\text { Nonexposed } \\
\quad(n=34)\end{array}$} \\
\hline & $M$ & $S D$ & $M$ & $S D$ & $M$ & $S D$ & $M$ & SD \\
\hline Infant sex ( $\%$ female $) \dagger$ & 53.3 & & 36.4 & & 59.3 & & 67.7 & \\
\hline Birth weight $(g)$ & $3,447.80$ & 259.70 & $3,262.23$ & 487.07 & $3,522.70$ & 455.11 & $3,571.35$ & 446.91 \\
\hline Gestational age (weeks) $†$ & 38.90 & 1.25 & 38.98 & 1.35 & 39.46 & 1.22 & 39.34 & 1.11 \\
\hline Age at NTA assessment (weeks) & 4.20 & 0.45 & 4.08 & 0.50 & 4.12 & 0.39 & 4.20 & 0.48 \\
\hline Maternal age at delivery (years) & 29.92 & 5.94 & 26.16 & 4.83 & 25.97 & 5.82 & 29.49 & 5.56 \\
\hline Maternal education (years)* & 13.80 & 2.01 & 14.05 & 2.06 & 13.70 & 1.88 & 14.94 & 1.65 \\
\hline \multicolumn{9}{|l|}{$\begin{array}{l}\text { Self-reported smoking } \\
\text { (cigarettes/day) }\end{array}$} \\
\hline Before last menstrual period & $8.38(n=14)$ & 7.05 & & & $9.34(n=26)$ & 8.31 & & \\
\hline 16 weeks & $4.10(n=10)$ & 6.61 & & & $3.21(n=24)$ & 6.86 & & \\
\hline 28 weeks & 2.47 & 4.19 & & & $2.38(n=26)$ & 4.25 & & \\
\hline At delivery & 2.27 & 3.94 & & & $1.81(n=26)$ & 3.41 & & \\
\hline At NTA assessment & $1.79(n=14)$ & 3.72 & & & 2.10 & 3.78 & & \\
\hline \multicolumn{9}{|l|}{ Cotinine levels } \\
\hline $\begin{array}{l}16 \text { weeks (maternal urine; } \\
\text { ng/mL)* }\end{array}$ & $\begin{array}{l}552.73 \\
(n=11)\end{array}$ & 799.11 & $\begin{array}{r}2.74 \\
(n=19)\end{array}$ & 6.15 & $\begin{array}{l}289.08 \\
(n=25)\end{array}$ & 579.53 & $\begin{array}{r}2.93 \\
(n=27)\end{array}$ & 11.87 \\
\hline $\begin{array}{l}28 \text { weeks (maternal urine; } \\
\mathrm{ng} / \mathrm{mL})^{*}\end{array}$ & 398.80 & 697.51 & 6.14 & 12.46 & 307.59 & 571.45 & 10.82 & 23.03 \\
\hline $\begin{array}{l}\text { At delivery (infant meconium; } \\
\mathrm{ng} / \mathrm{g})\end{array}$ & ; 122.27 & 231.41 & $\begin{array}{r}0.00 \\
(n=21)\end{array}$ & 0.00 & $\begin{array}{l}136.08 \\
(n=25)\end{array}$ & 603.88 & $\begin{array}{r}1.80 \\
(n=30)\end{array}$ & 7.25 \\
\hline $\begin{array}{l}\text { At NTA assessment (infant } \\
\text { urine; } \mathrm{ng} / \mathrm{mL} \text { ) }\end{array}$ & $\begin{array}{r}16.92 \\
(n=14)\end{array}$ & 24.13 & $\begin{array}{r}11.68 \\
(n=19)\end{array}$ & 18.83 & $\begin{array}{r}20.00 \\
(n=22)\end{array}$ & 25.96 & $\begin{array}{r}10.18 \\
(n=30)\end{array}$ & 21.28 \\
\hline
\end{tabular}

NTA = Neonatal Temperament Assessment.

* Differs significantly by exposure group, $p<.05$.

† Differs significantly by genotype group. 
voice) was rated on a 4-point scale. Stress reactivity was assessed by rating the infant's response to repeated application of a metal disc, cooled by immersion in ice water, against the infant's thigh and rating the infant's reactivity to orientation and reflex elicitation procedures. Level of irritability (rated on a 6-point scale) and latency to fuss or cry were scored. Between stress reactivity trials, the examiner actively soothed the baby if necessary and scored the latency to soothe. Soothability and stress reactivity also were assessed via repeated pacifier presentation and withdrawal. Interobserver reliability was checked on $5 \%$ of assessments by having a second examiner co-score all items. Correlation coefficients were computed for each module of items. Average correlations were calculated for attention $(M=.92$; range $=.72-1.00)$, stress reactivity $(M$ $=.99$; range $=.98-1.00)$, pacifier presentation and withdrawal $(M=.99$; range $=.98-1.00)$, soothability $(M=.99$; range $=.91-$ $1.00)$, and summary scores $(M=.89$; range $=.48-1.00)$. Reliability across all items was .95 (range $=.85-1.00)$.

\section{Statistical Methods}

All analyses were conducted using SAS 9.1 (SAS Institute, Cary, NC). SAS's Proc Factor was used to reduce the obtained data to summary factor scores using principal axis factor analysis with Promax rotation. Factor analyses were conducted using the larger sample of neonates (including those not yet genotyped) to provide a more stable estimate of factor loadings (see Espy et al., 2008, for details). Items and factor loadings for the best-fitting, three-factor solution are listed in Table 2 , along with interfactor correlations for the present sample. On the basis of the items loading on each factor, the factors were labeled Irritable Reactivity, Attention, and Stress Dysregulation. SAS's Proc Mixed was used to analyze the effects of TaqIA genotype (A1+, A1-), PTE (dichotomously coded as PTE, NE [nonexposed]), ${ }^{2}$ and their interaction on each factor separately. Interactions were interpreted using simple effects. Sex and age at assessment were included as covariates in all models because they have been shown in other studies to relate to neonatal behavior (e.g., Riese, 1984). Maternal education and infant birth weight were controlled statistically in all analyses because they differed by exposure group and genotype, respectively, and because in several previous studies, birth weight mediated the effect of PTE on behavior outcome (Huijbregts et al., 2006; Nigg \& Breslau, 2007), although there were no differences in birth weight between exposure groups in the present sample.

\section{Results}

For the Attention factor, there was a main effect of TaqIA genotype, $F(1,90)=4.34, p<.05$, that was qualified by a significant interaction between genotype and exposure status, $F(1,90)=8.73, p<.005$. This interaction is illustrated in the top panel of Figure 1. Among NE neonates, those with the at-risk, A1+ genotype were more attentive to stimuli than were those with the A1- genotype, $F(1,90)=13.83, p<.0005$. In contrast,
Table 2. Neonatal Temperament Assessment Factor Structure and Observed Interfactor Correlations

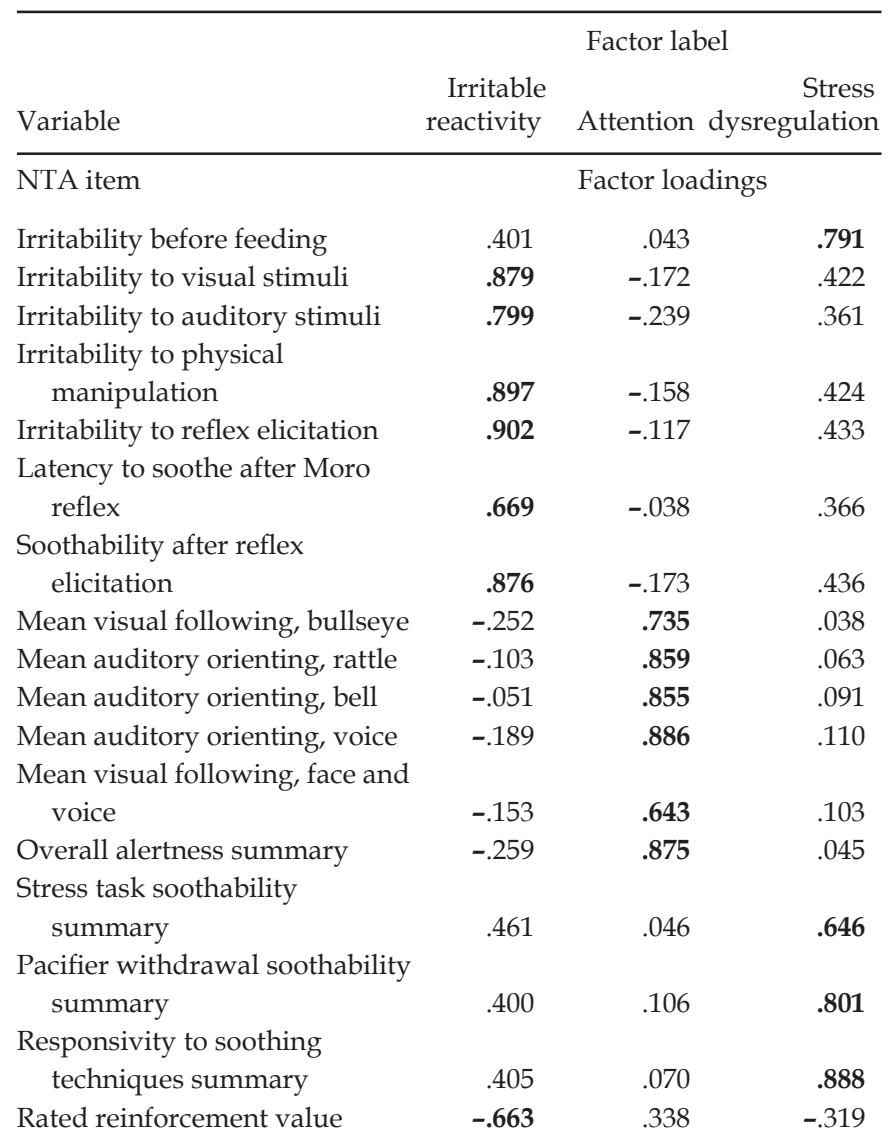

Sample factor score correlations

Factor label

Irritable Reactivity

Attention

Stress dysregulation

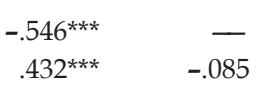

Factor loadings above .60 are presented in bold.

*** $p<.0001$

among PTE infants, the Attention factor scores were comparable in $\mathrm{A} 1+$ and A1- infants, $F(1,90)=0.32, p>.57$. There was no main effect of exposure status, $F(1,90)=0.08, p>.77$. The maternal education covariate accounted for significant variance in Attention scores, $F(1,90)=5.93, p<.05$, and the effect of birth weight approached significance, $F(1,90)=2.86, p<.10$. Higher levels of education and higher birth weights were associated with increased Attention scores. The other covariates were unrelated to Attention score ( $p$ s > .95).

For the Irritable Reactivity factor, there was a significant interaction between genotype and PTE paralleling that seen for

\footnotetext{
${ }^{2}$ As shown in Table 1, infants in the PTE group varied in the amount of tobacco exposure during pregnancy. Our analytic approach is to first explore the effect of PTE by initially conducting analyses using a dichotomous grouping of tobacco exposure, and then to test possible dose-response effects within the PTE group by examining relations between behavioral outcomes and self-report and cotinine indices of exposure (for a similar approach, see Gaultney et al., 2005). In this report, results from the first stage of analysis are presented. After the remaining participants in this sample are genotyped, statistical power will be increased to address the continuously distributed dose effect within the PTE subsample, and the next step will be to examine the effects of the topography (e.g., amount, duration, and timing) of tobacco exposure on neonatal behavior.
} 

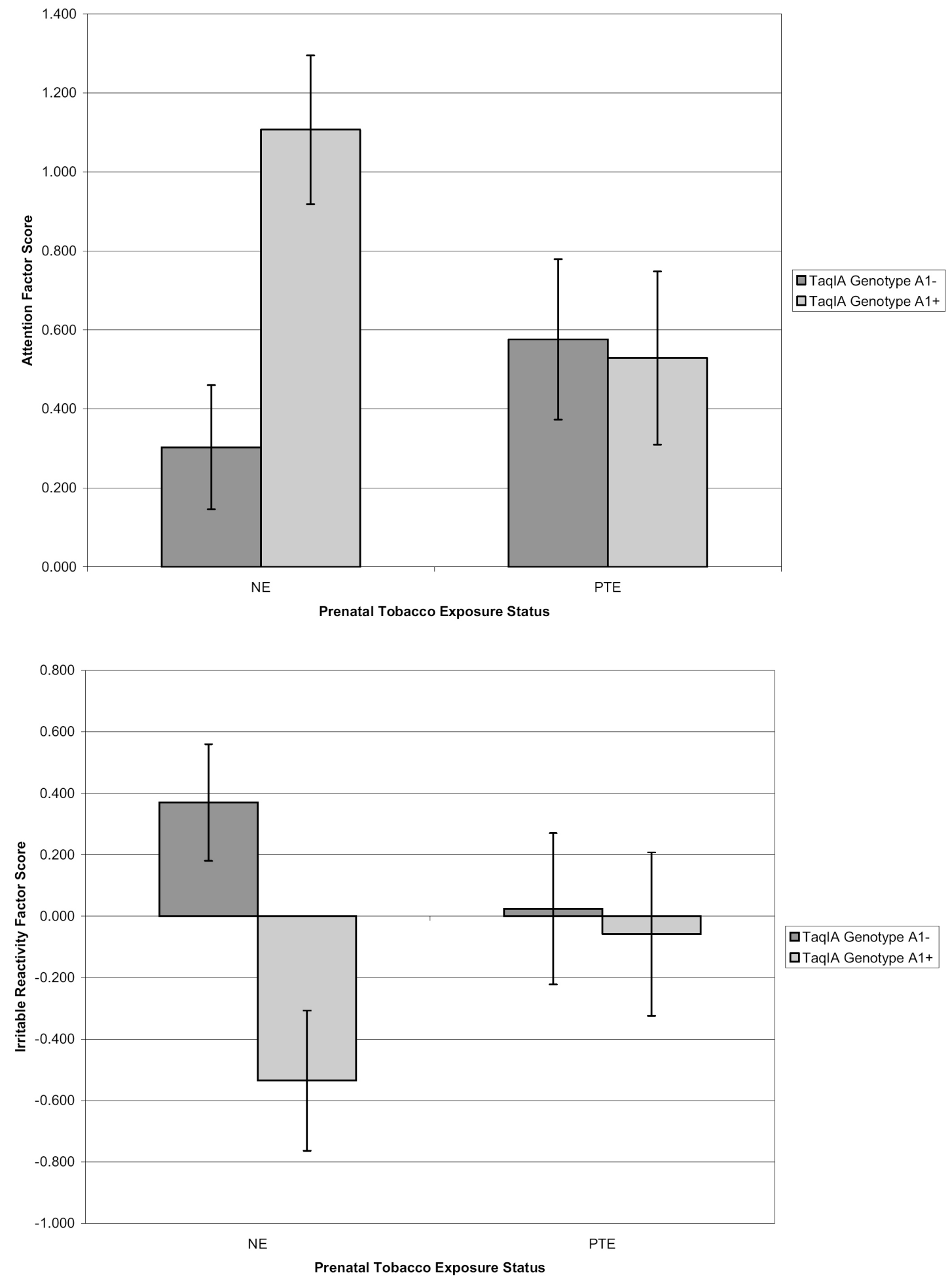

口TaqIA Genotype A1-

口TaqIA Genotype A1+

Figure 1. Neonatal attention and irritable reactivity, by TaqIA genotype and prenatal tobacco exposure, controlling for maternal education, sex, and age at assessment. $\mathrm{NE}=$ no exposure, $\mathrm{PTE}=$ prenatal tobacco exposure. Error bars represent standard error.

Attention, $F(1,90)=7.20, p<.01$. Genotype-related differences in reactivity were pronounced in NE infants, $F(1,90)=10.02, p$ $<.005$, but not in PTE infants, $F(1,90)=0.50, p>.48$. The main effect for genotype did not reach significance, $F(1,90)=2.58$, $p>.11$, and there was no effect of exposure status, $F(1,90)=$
$0.01, p>$.93. Irritable Reactivity scores were unrelated to any covariate (all $p \mathrm{~s}>.39$ ).

For the Stress Dysregulation factor, neither the main effects of genotype or exposure status nor their interaction were significant $(p s>34)$. There was a significant sex difference, $F(1$, 
$90)=5.49, p<.05$. Girls had higher factor scores $(M=0.61, S E$ $=0.155)$ than boys $(M=0.19, S E=0.162)$, indicating that they were less able to regulate their stress responses to assessment procedures and were less responsive to active soothing by the examiner. Stress Dysregulation scores were not related to the remaining covariates ( $p s>.27)$.

\section{Discussion}

For two dimensions of neonatal behavior, attention and irritable reactivity, the effect of PTE differed by TaqIA genotype. In nonexposed neonates, those with the A1+ genotype (typically identified as the higher risk allele) were more attentive to the auditory and visual stimuli and were less irritable to these stimuli and routine handling, relative to those with the A1allele. In neonates who were exposed to tobacco during pregnancy, there were no differences in these behaviors between infants with and without the A1 allele. At first glance, the direction of the effect observed in nonexposed infants was unexpected. One explanation may lie in genotype-related differences in the processing of novel information. The A1+ genotype has been associated with higher levels of novelty seeking (Berman et al., 2002). The Attention factor score was composed primarily of items indexing orientation to unfamiliar stimuli, such as the examiner's face and voice, rattle, bell, and bulls-eye. Observed differences in attention to novel information early in development may reflect variation in nervous system responsivity that is a precursor to the novelty-seeking personality observable later in life. Prenatal exposure to nicotine has been associated with decreased response to novelty in rats (Vaglenova et al., 2004) and nonhuman primates (Golub, Slotkin, Tarantal, \& Pinkerton, 2007). PTE may attenuate the increased attentiveness to novelty in neonates with the A1+ genotype, resulting in no difference from those PTE infants with the A1- genotype.

Furthermore, the parallel findings observed for the Attention and Irritable Reactivity domains may be connected: Beginning late in the first year of life, redirection of attention becomes an important strategy for emotion regulation, as children distract themselves from unpleasant yet uncontrollable circumstances to reduce distress (Bridges \& Grolnick, 1995; Wilson \& Gottman, 1996). Kopp (1989) has suggested that attention and emotion regulation are closely interrelated in early development. Consistent with this postulation, the Attention and Irritable Reactivity factors were significantly correlated $(r=-.55)$, with almost $30 \%$ shared variance. Critically, this shared variability is not due to shared items, in that there is very little overlap in items that load highly on these two factors. Rather, many of the items tapped differing aspects of the same NTA assessment modules (e.g., infants' orientation response and rated irritability to visual stimuli). It may be that infants who respond to novel stimuli with an obligatory orienting response are less likely to become irritable, as their increased attentiveness serves to modulate negative emotionality (albeit without effortful control on the part of the neonate). Admittedly, these findings were unexpected, and as such, replication and further studies to elucidate possible underlying mechanisms are critical.

\section{Study 2: Preschool Executive Control}

The preschool years are an important period in the maturation of frontal structures and their connections to corti- cal and subcortical regions (Giedd et al., 1999; Thatcher, 1994) and the concomitant development of executive control of cognition and behavior. During this transition, young children are increasingly required to regulate their cognitive processes and affective expression in the course of their everyday lives in contexts outside the family and home environment; they must modulate their behavior to participate in group settings (e.g., day care or preschool) or public places (e.g., the grocery store), for example, when they are required to tolerate delays for gratification.

The Trail Making Test (Reitan, 1955) was developed to assess frontal lobe dysfunction in adult patient populations. In this task, participants connect stimuli on a page in sequence. In the control condition (Condition A), participants connect letters only, whereas in the switch condition (Condition B), participants must alternate between letters and numbers in sequence. The standard form of this task has been used successfully in older children and adolescents (Emerson, Mollet, \& Harrison, 2005). However, because preschool children have emerging literacy and numeracy skills, the standard test lacks validity in young children. Recently, Espy and Cwik (2004) developed an adaptation for use with preschool children, the Preschool Trail Making Test (Trails-P). In the present study, typically developing preschool children completed the Trails-P and were genotyped on the TaqIA allele. Information was collected retrospectively about PTE, permitting exploratory analyses of $G \times E$ interactive effects. However, the proportion of children who had been prenatally exposed to tobacco was substantially lower than in Study 1. The original goal of the preschool study was not related to prenatal exposure, and thus there was no oversampling for exposure. Therefore, retrospective interviews may have led to underreporting of prenatal exposure, which must be considered in interpreting the obtained results.

\section{Method}

Participants. The sample included 58 typically developing preschool children (mean age, 4 years 6 months; range, 3 years 0 months to 6 years 1 month). Demographic information is summarized in Table 3. As in Study 1, all children included in the present analysis were of White European ethnicity (see Footnote 1).

Procedure. All children were assessed individually in a child research laboratory. Parents provided written informed consent for their children's participation, and then children completed a task battery that included the Trails-P. Buccal cells were collected through a child-friendly "lollipop taste

Table 3. Sample Demographics, by TaqIA Genotype Group

\begin{tabular}{|c|c|c|c|c|}
\hline \multirow[b]{2}{*}{ Demographic variable } & \multicolumn{2}{|c|}{$\begin{array}{c}\text { A1 Carriers } \\
(\mathrm{A} 1 \mathrm{~A} 1, n=2 ; \\
\text { A1A2, } n=25)\end{array}$} & \multicolumn{2}{|c|}{$\begin{array}{c}\text { A1 Noncarriers } \\
\text { (A2A2, } \\
n=31)\end{array}$} \\
\hline & $M$ & $S D$ & $M$ & $S D$ \\
\hline Gender ( $\%$ female) & $59 \%$ & & $55 \%$ & \\
\hline Age at assessment (years) & 4.5 & 0.77 & 4.6 & 0.79 \\
\hline Maternal education (years)* & 12.9 & 1.82 & 14.9 & 2.64 \\
\hline $\begin{array}{l}\text { Prenatal tobacco exposure } \\
\text { (\% exposed) }\end{array}$ & $15 \%$ & & $13 \%$ & \\
\hline
\end{tabular}

${ }^{*}$ Differs significantly by genotype group, $p<.05$ 
test" game (Espy \& Hamby, 2002). Parents completed a brief interview, including information about maternal educational attainment and smoking during pregnancy.

The Trails-P is administered in a storybook format, where each condition is composed of an array of stimuli (a family of dogs that vary in size) distributed on a page. Children completed the task by marking the stimuli in order from smallest to biggest with a happy-face stamper. Before beginning the task, they were given practice using the stamper and identifying the dogs in order of size on a practice page. In the control condition, children marked dogs only, whereas in the switch condition, children alternated between dogs and bones. In the inhibit condition, children again stamped dogs only, but bones were also present on the page, serving as potential distractors. Each page required six responses. As in the adult version of the Trail Making Test, feedback was given, and children were required to correct any errors, so that all stimuli were marked to complete a condition. The examiner scored the number of errors and latency to complete each condition during the assessment. Several children had missing data for one or more conditions ( $n=1,2$, and 5 for the control, switch, and inhibit conditions, respectively) due to examiner error or because the child refused to complete all task conditions.

Genotyping was conducted using procedures identical to those in Study 1. The observed allele frequencies did not differ from Hardy-Weinberg equilibrium, $\chi^{2}(1, N=58)=1.80, p$ $=.18$. PTE status was determined retrospectively on the basis of maternal self-report at the time of the preschool assessment. Retrospective recall may have resulted in underreporting of prenatal smoking (Bardy et al., 1993), although some studies have found that retrospective reporting of smoking is consistent with prospective data as long as 4 years later (Jacobson, Chiodo, Sokol, \& Jacobson, 2002). Because this study sample was typically developing and was not selected on the basis of prenatal risk factors, reported smoking during pregnancy was substantially less frequent (14\%) than in Study 1, resembling the rate reported in nonselected samples to reflect prevalence in the general population (Centers for Disease Control and Prevention, 2005). The proportion of mothers who reported smoking during pregnancy did not differ by child TaqIA genotype or sex, $\chi^{2}(1, N=58)=.04$ and $0.18, p s>.67$, respectively.

\section{Results}

The number of errors was analyzed using Proc Mixed in SAS 9.1. TaqIA genotype (A1+, A1-), Trails-P condition (control, switch, inhibit), PTE status (tobacco-exposed, nonexposed), and their interactions were modeled as fixed effects, and subject was modeled as a random effect. Child age (in months) and maternal education were included as fixed effect covariates to control for their potential influence on performance. Models were trimmed in a backward stepwise manner, where nonsignificant interactions $(p>.10)$ were dropped from the model. There was a significant genotype by task condition interaction, $F(2,54)=3.07, p=.05$, and a main effect of genotype, $F(1,54)=4.27, p<.05$, but no main effect of task condition, $F(2,54)=1.31, p>.28$. As shown in Figure 2, analyses of the simple effects of genotype within each condition showed that children with the A1+ allele made significantly more errors than children with the A1- allele in the switch condition, $F(1,54)=5.06, p<.03$, and in the inhibit condition, $F(1,54)=4.80, p<.04$, but errors were equivalent between genotype groups for the control condition, $F(1,54)=0.55, p=.46$. Number of errors was only marginally related to age, $F(1,54)$ $=3.26, p<.08$, and was unrelated to maternal education, $F(1$, 54) $=0.63, p>.43$.

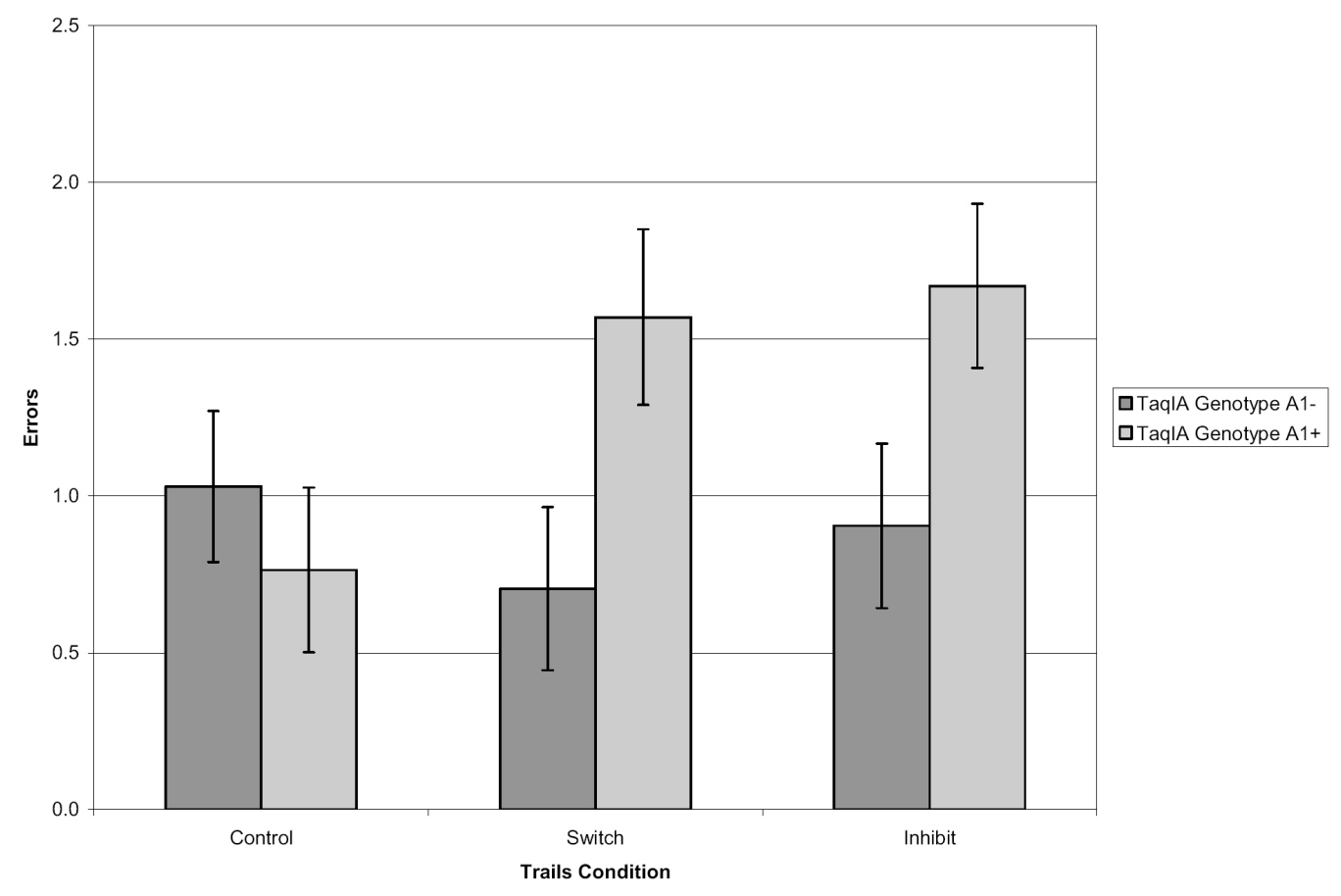

Figure 2. Preschool Trail Making Test error rate, by task condition and TaqIA genotype, controlling for maternal education and age at assessment. Error bars represent standard error. 
Further exploratory analyses were conducted including PTE status, but these results must be taken with caution because of the low frequency of tobacco exposure in this sample. When PTE status was added to the model, the genotype by task condition interaction remained significant, and there was no hint of a three-way interaction with PTE $(p>.66)$. There was a significant interaction of TaqIA genotype and PTE status, $F(1,52)=6.97, p<.02$. This interaction is shown in Figure 3 . For children whose mothers reported smoking during pregnancy, the effect of TaqIA genotype was significant, $F(1$, $52)=10.62, p<.005$. Collapsed across all conditions, children with the A1+ genotype made more errors than children with the A1- genotype. For children whose mothers did not report smoking during pregnancy, there was no difference in the number of errors between genotype groups, $F(1,52)=1.15, p>$ .29. Viewed another way, the effect of PTE status was specific to children with the A1+ genotype, $F(1,52)=6.00, p<.02$, and A1- children performed equivalently independent of prenatal exposure status, $F(1,52)=1.30, p>.26$. Parallel analyses were conducted for response latencies, and these revealed no significant effects of genotype $(p>.29)$ or PTE $(p>.23)$.

\section{Discussion}

As predicted, children's Trails-P performance, a task with substantial demands for executive control of cognition, differed by the child's TaqIA genotype. Children with the A1+ genotype made more errors, but only in those task conditions posited to require greater executive control (i.e., switch and inhibit). TaqIA genotype is associated with variation in DRD2 receptor expression in the basal ganglia, which likely supports differences in the efficiency of dopaminergic neurotransmission in these regions. Variations in signaling efficiency might contribute to failure to maintain the stimulus-response rules for the executive conditions, indicated by errors in stamping the stimuli out of sequence. These condition-specific differences were evident even though overall numbers of errors did not differ by condition, and they were robust when PTE was added to the model.

The exploratory analyses incorporating PTE must be interpreted with caution because of the small number of children whose mothers reported smoking during pregnancy. Retrospective report of PTE depends on the accuracy of mothers' memories and their willingness to disclose smoking during pregnancy. Preschoolers whose mothers failed to report smoking would have been misclassified as nonexposed, reducing apparent differences between the groups and working against our hypotheses. There was a statistically significant interaction between PTE and DRD2 genotype, where preschoolers with both PTE exposure and the high-risk A1 allele made the most errors in the task across all task conditions regardless of executive control requirements. Although this finding is intriguing, replication in a larger, prospective sample is required before any conclusions are made. In future work, children should be assessed within more narrow age bands to examine whether the genotype by exposure interaction varies at discrete ages within the preschool period. Although the present study did not reveal evidence for such variation, children were recruited to cover the preschool period more broadly, which precluded formally testing this hypothesis.

\section{General Discussion}

Genes have their effect on behavioral outcomes through expression across development, modulated by environmental factors (Caspi \& Moffitt, 2006). However, few studies have examined the interaction between genetic and environmen-

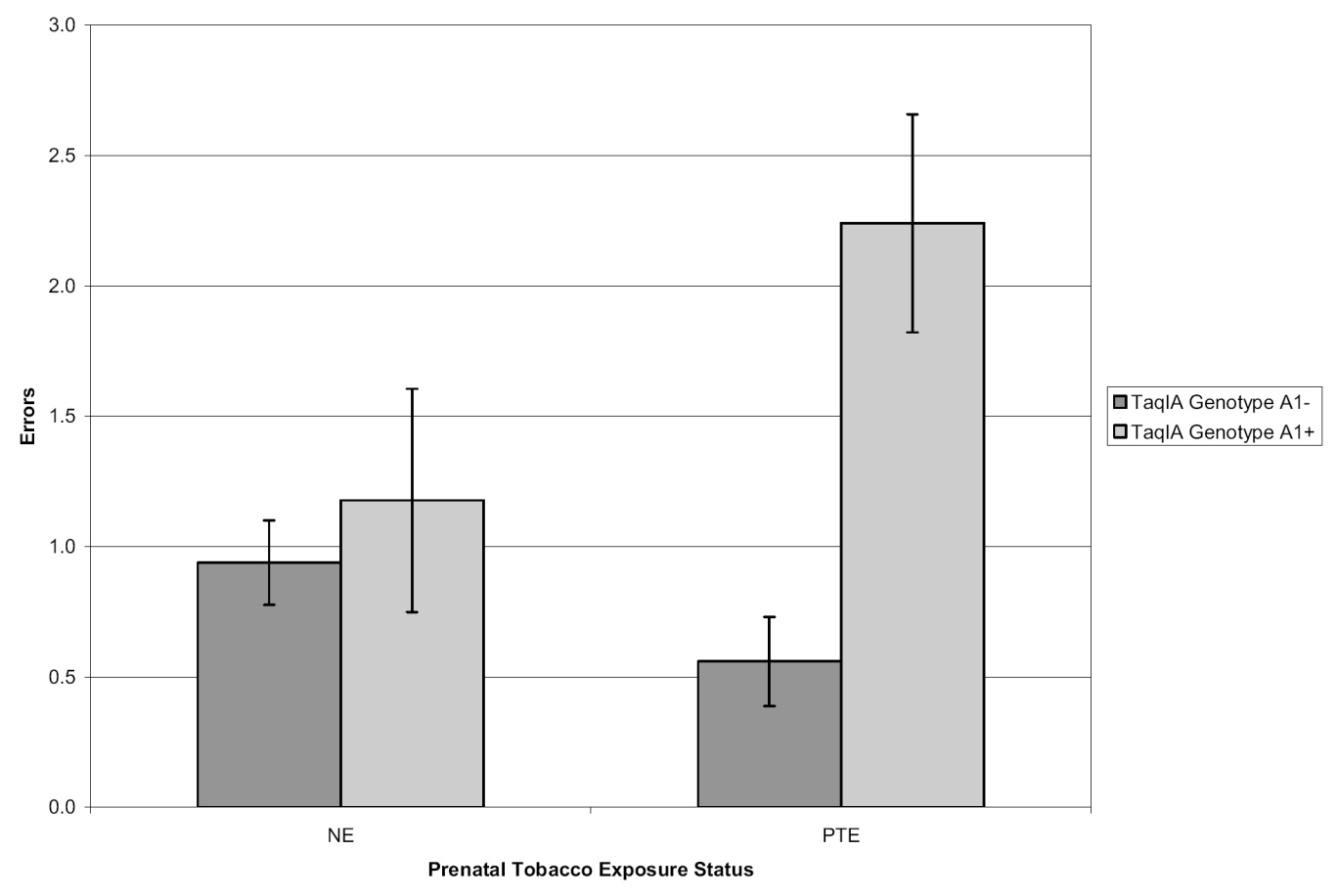

Figure 3. Preschool Trail Making Test error rate, by TaqIA genotype and prenatal tobacco exposure, controlling for maternal education and age at assessment. Error bars represent standard error. 
tal factors at different critical periods in development. In this study, we explored the interaction between DRD2 genotype and PTE within two distinct developmental periods. In early infancy, behavioral regulation is primarily accomplished by early-maturing neural systems responsible for alertness and orienting (Posner \& Rothbart, 2007), whereas in the preschool period, the prefrontal circuits underlying executive control are undergoing rapid development, although maturation is not complete until late adolescence (Giedd et al., 1999). At 4 weeks, neonates with the A1+ genotype showed greater attention and less irritable reactivity to auditory-visual stimuli in the absence of PTE, whereas for infants whose mothers did not smoke during pregnancy, these genotype-related differences were not apparent. In contrast, preschool children with the A1+ genotype associated with decreased DRD2 expression and availability made more errors on Trails-P conditions requiring executive control, suggesting that they had difficulty updating and maintaining the current condition rule. In the subsample of children who had the higher risk A1+ genotype and whose mothers reported smoking during pregnancy, increased difficulties were observed across all task conditions.

A fundamental question is that of how early functioning relates to later outcomes. Differences in neural microstructure and synaptic efficiency and associated behavioral phenotypes likely bias the course of later development directly and through further interactions with the environment (e.g., through eliciting particular types of caregiving behavior in the case of irritable temperament). Understanding these pathways is critical in that it will allow identification of children who are most at risk and may benefit from intervention. However, the findings across the two studies presented here are not directly comparable because of the differences in sampling and methods. In Study 1, nonexposed infants with the A1+ genotype evidenced what might be considered "better" performance - that is, higher levels of attention and less irritable reactivity. Within the context of neonatal assessment, where a strange adult has taken charge of the infant to administer a variety of unfamiliar procedures, the most adaptive response might in fact be irritable reactivity to summon the caregiver's assistance. Even in typically developing children, relations between early and later assessments are not always straightforward. For example, infants who performed better on the A-not-B task at age 9 months performed more poorly on an interference control task at age 2 years (Holmboe, Fearon, Csibra, Tucker, \& Johnson, 2008). Similarly, precocious reading ability may be a marker for autism spectrum disorder (Nation, Clarke, Wright, \& Williams, 2006). Longitudinal studies are necessary to permit consideration of findings in early development in light of later functional outcomes. To begin to address this issue, we plan further follow-up of the Study 1 neonatal sample.

More broadly, other postnatal environmental factors must be considered as moderators of the effects of genetic and prenatal environmental risk factors on developmental outcomes. In the research presented here, we attempted to reduce the influence of other environmental factors such as socioeconomic status, birth weight, or prenatal alcohol exposure through targeted recruitment and selective enrollment in Study 1 and through statistical control in both studies. These procedures, though, do not ensure complete equivalence between exposure groups on measured and unmeasured variables. For example, postnatal tobacco exposure is inevitably correlated with prenatal exposure and also is associated independently with behavioral outcomes (Day et al., 2000; Herrmann, King, \& Weitzman, 2008). In Study 1, the amount of postnatal tobacco exposure is likely minimal relative to that incurred prenatally, in that behavioral assessment took place only weeks after birth when many women who quit prenatally have not yet relapsed. In the present sample, $61 \%$ of mothers in the PTE group reported that they had not smoked any cigarettes between their baby's birth and the time of the infant assessment, and all but one mother reported restrictions on cigarette smoking in the home. Substantiating the veracity of maternal report, infants' urine cotinine levels at the time of assessment did not differ significantly by exposure group, $F(1,83)=2.69, p>.10$. Unfortunately, data on postnatal exposure are not available for the Study 2 sample.

Sociocultural factors are particularly important to consider in emerging self-regulation because children's regulatory competence has been linked to parenting style and home characteristics (Calkins et al., 1998; Diener, Mangelsdorf, McHale, \& Frosch, 2002; K. G. Noble et al., 2005). Children's executive control skill is responsive to school-based intervention, providing further evidence for plasticity (Diamond, Barnett, Thomas, \& Munro, 2007). Contextual factors may affect some children more than others, depending on their genetic liability (Caspi et al., 2002). Child-driven effects are also plausible. For example, early differences in temperament resulting from the interplay of genetic factors and the prenatal environment might elicit differences in caregiver responsivity and hence the quality of parent-child interaction (cf. Scarr \& McCartney, 1983).

Although this discussion has centered on the DRD2 TaqIA genotype, the effect of any candidate gene is undoubtedly qualified by other genetic and environmental influences. The dopaminergic system involves the interplay of many receptor subtypes, along with molecules involved in the production of dopamine and regulation of synaptic dopamine levels. Multiple genes likely are involved, and designs involving multiple candidate genes may reveal gene-gene interactions (e.g., Eisenberg et al., 2007). Variations in genotype may also contribute to prenatal exposure effects. Women who smoke throughout pregnancy, women who quit smoking during pregnancy, and women who do not smoke differ in genetic liability (Agrawal et al., 2008), and the A1+ genotype is itself associated with nicotine dependence (Gelernter et al., 2006). Unmeasured genetic liability that is shared between mother and offspring cannot be distinguished from prenatal exposure effects in the current study design.

Despite these challenges, the field has made tremendous progress in conceptualizing how genes and environment interact to shape developmental outcomes. Such steps forward have resulted in part from technological advances in genetics and the identification of specific candidate genes related to behavioral phenotypes. However, genetic studies must be accompanied by careful consideration of prenatal risk factors such as maternal smoking and postnatal environmental factors such as parenting and postnatal tobacco exposure that further shape the emergence of behavioral competencies, including the capacity to regulate cognition and emotion. If we are to truly understand the dynamic developmental unfolding of these abilities, constructs must be measured across time, preferably using longitudinal designs, as the interaction of nature and nurture may differ in its expression in different critical maturational periods. 


\section{References}

Agrawal, A., Knopik, V. S., Pergadia, M. L., Waldron, M., Bucholz, K. K., Martin, N. G., et al. (2008). Correlates of cigarette smoking during pregnancy and its genetic and environmental overlap with nicotine dependence. Nicotine $\mathcal{E}$ Tobacco Research, 4, 567-578.

Anghelescu, I., Germeyer, S., Müller, M. J., Klawe, C., Singer, P., Dahmen, N., et al. (2001). No association between the dopamine D2 receptor TaqI A1 allele and earlier age of onset of alcohol dependence according to different specified criteria. Alcoholism: Clinical and Experimental Research, 25, 805-809.

Azam, L., Chen, Y., \& Leslie, F. M. (2007). Developmental regulation of nicotinic acetylcholine receptors within midbrain dopamine neurons. Neuroscience, 144, 1347-1360.

Bakermans-Kranenburg, M. J., \& van Ijzendoorn, M. H. (2006). Gene-environment interaction of the dopamine D4 receptor (DRD4) and observed maternal insensitivity predicting externalizing behavior in preschoolers. Developmental Psychobiology, 48, 406-409.

Bardy, A. H., Kataja, J. M., \& Pikkarainen, J. (1993). Objectively measured tobacco exposure during pregnancy: Neonatal effects and relation to maternal smoking. British Journal of $\mathrm{Ob}$ stetrics and Gynecology, 100, 721-726.

Barr, C. L., \& Kidd, K. K. (1993). Population frequencies of the A1 allele at the dopamine $\mathrm{D}_{2}$ receptor locus. Biological Psychiatry, 34, 204-209.

Becker, K., El-Faddagh, M., Schmidt, M. H., Esser, G., \& Laucht, M. (2008). Interaction of dopamine genotype with prenatal smoke exposure on ADHD symptoms. Journal of Pediatrics, $152,263-269$.

Berke, J. D., \& Hyman, S. E. (2000). Addiction, dopamine, and the molecular mechanisms of memory. Neuron, 25, 515-532.

Berman, S., Ozkaragoz, T., Young, R. M., \& Noble, E. P. (2002). D2 dopamine receptor gene polymorphism discriminates two kinds of novelty seeking. Personality and Individual Differences, 33, 867-882.

Berns, G. S., Cohen, J. D., \& Mintun, M. A. (1997, May23). Brain regions responsive to novelty in the absence of awareness. Science, 276, 1272-1275.

Bishop, S. J., Cohen, J. D., Fossella, J., Casey, B. J., \& Farah, M. J. (2006). COMT genotype influences prefrontal response to emotional distraction. Cognitive, Affective, \& Behavioral Neuroscience, 6, 62-70.

Bishop, S. J., Duncan, J., Brett, M., \& Lawrence, A. D. (2004). Prefrontal cortical function and anxiety: Controlling attention to threat-related stimuli. Nature Neuroscience, 7, 184-188.

Blum, K., Noble, E. P., Sheridan, P. J., Montgomery, A., Ritchie, T., Jagadeeswaran, P., et al. (1990). Allelic association for human dopamine D2 receptor gene in alcoholism. Journal of the American Medical Association, 263, 2055-2060.

Bridges, L. J., \& Grolnick, W. S. (1995). The development of emotional self-regulation in infancy and early childhood. In N.Eisenberg (Ed.), Review of personality and social psychology (Vol. 15, pp. 185-121). New York: Sage.

Bronfenbrenner, U., \& Ceci, S. J. (1994). Nature-nurture in developmental perspective: A bioecological theory. Psychological Review, 101, 568-586.

Calkins, S. D., Smith, C. L., Gill, K. L., \& Johnson, M. C. (1998). Maternal interactive style across contexts: Relations to emotional, behavioral and physiological regulation during toddlerhood. Social Development, 7, 350-369.
Carlson, S. M. (2005). Developmentally sensitive measures of executive function in preschool children. Developmental Neuropsychology, 28, 595-616.

Caspi, A., McClay, J., Moffitt, T. E., Mill, J., Martin, J., Craig, I. W., et al. (2002, August2). Role of genotype in the cycle of violence in maltreated children. Science, 297, 851-854.

Caspi, A., \& Moffitt, T. E. (2006). Gene-environment interactions in psychiatry: Joining forces with neuroscience. Nature Reviews Neuroscience, 7, 583-590.

Centers for Disease Control and Prevention. (2005). Cigarette smoking among adults-United States, 2004. Morbidity and Mortality Weekly Report, 54, 1121-1124.

Cicchetti, D., Rogosch, F. A., \& Sturge-Apple, M. L. (2007). Interactions of child maltreatment and serotonin transporter and monoamine oxidase A polymorphisms: Depressive symptomatology among adolescents from low socioeconomic status backgrounds. Development \& Psychopathology, 19, 1161-1180.

Cohen, M. X., Young, J., Baek, J.-M., Kessler, C., \& Ranganath, C. (2005). Individual differences in extraversion and dopamine genetics predict neural reward responses. Cognitive Brain Research, 25, 851-861.

Côté, S., Tremblay, R. E., \& Nagin, D. S. (2002). Childhood behavioral profiles leading to adolescent conduct disorder: Risk trajectories for boys and girls. Journal of the American Academy of Child and Adolescent Psychiatry, 41, 1086-1094.

David, S. P., Strong, D. R., Munafò, M. R., Brown, R. A., LloydRichardson, E. E., Wileyto, P. E., et al. (2007). Bupropion efficacy for smoking cessation is influenced by the DRD2 Taq1A polymorphism: Analysis of pooled data from two clinical trials. Nicotine \& Tobacco Research, 9, 1251-1257.

Day, N. L., Richardson, G. A., Goldschmidt, L., \& Cornelius, M. D. (2000). Effects of prenatal tobacco exposure on preschoolers' behavior. Developmental and Behavioral Pediatrics, 21, 180-188.

Day, N., \& Robles, N. (1989). Methodological issues in the measurement of substance abuse. Annals of the New York Academy of Sciences, 562, 8-13.

Delgado, M. R., Locke, H. M., Stenger, V. A., \& Fiez, J. A. (2003). Dorsal striatum responses to reward and punishment: Effects of valence and magnitude manipulations. Cognitive, Affective, $\mathcal{E}$ Behavioral Neuroscience, 3, 27-38.

Diamond, A., Barnett, W. S., Thomas, J., \& Munro, S. (2007, November30). Preschool program improves cognitive control. Science, 318, 1387-1388.

Diamond, A., Briand, L., Fossella, J., \& Gehlbach, L. (2004). Genetic and neurochemical modulation of prefrontal cognitive functions in children. American Journal of Psychiatry, 161, 125-132.

Diener, M. L., Mangelsdorf, S. C., McHale, J. L., \& Frosch, C. A. (2002). Infants' behavioral strategies for emotion regulation with fathers and mothers: Associations with emotional expressions and attachment quality. Infancy, 3, 153-174.

Ducci, F., Enoch, M. A., Hodgkinson, C., Xu, K., Catena, M., Robin, R. W., \& Goldman, D. (2008). Interaction between a functional MAOA locus and childhood sexual abuse predicts alcoholism and antisocial personality disorder in adult women. Molecular Psychiatry, 13, 334-347.

Duncan, J., \& Owen, A. M. (2000). Common regions of the human frontal lobe recruited by diverse cognitive demands. Trends in Neuroscience, 23, 475-483.

Eisenberg, D. T. A., MacKillop, J., Modi, M., Beauchemin, J., Dang, D., Lisman, S. A., et al. (2007). Examining impulsivity as an endophenotype using a behavioral approach: A DRD2 TaqI A and DRD4 48-bp VNTR association study. Behavioral and Brain Functions, 3, 2 
Emerson, C. S., Mollet, G. A., \& Harrison, D. W. (2005). Anxiousdepression in childhood: An evaluation of executive functions. Archives of Clinical Neuropsychology, 20, 539-546.

Erblich, J., Lerman, C., Self, D. W., Diaz, G. A., \& Bovbjerg, D. H. (2005). Effects of dopamine D2 receptor (DRD2) and transporter (SLC6A3) polymorphisms on smoking cue-induced cigarette craving among African-American smokers. Molecular Psychiatry, 10, 407-414.

Espy, K. A. (2004). Using developmental, cognitive, and neuroscience approaches to understanding executive control in young children. Developmental Neuropsychology, 26, 379-384.

Espy, K. A., \& Cwik, M. F. (2004). The development of a Trail Making Test in young children: The Trails-P. Clinical Neuropsychologist, 18, 411-422.

Espy, K. A., \& Hamby, A. F. (2002). "Getting into the mouths" of preschoolers: A method for obtaining buccal samples for later genotyping. Developmental Neuropsychology, 21, 197-200.

Espy, K. A., Kaufmann, P. M., Glisky, M. L., \& McDiarmid, M. D. (2001). New procedures to assess executive functions in preschool children. Clinical Neuropsychologist, 15, 46-58.

Espy, K. A., Stopp, C., Wiebe, S. A., Clayton, N. V., \& Respass, J. (2008). Prenatal tobacco exposure: Developmental impact on neonatal regulation. Manuscript submitted for publication.

Fossella, J., Green, A. E., \& Fan, J. (2006). Evaluation of a structural polymorphism in the ankyrin repeat and kinase domain containing 1 (ANKK1) gene and the activation of executive attention networks. Cognitive, Affective, \& Behavioral Neuroscience, 6, 71-78.

Fried, P. A., \& Watkinson, B. (1988). 12- and 24-month neurobehavioural follow-up of children prenatally exposed to marihuana, cigarettes and alcohol. Neurotoxicology and Teratology, 10, 305-313.

Fung, Y. K., \& Lau, Y.-S. (1989). Effects of prenatal nicotine exposure on rat striatal dopaminergic and nicotinic systems. Pharmacology, Biochemistry, \& Behaviour, 33, 1-6.

Gaultney, J. F., Gingras, J. L., Martin, M., \& DeBrule, D. (2005). Prenatal cocaine exposure and infants' preference for novelty and distractibility. Journal of Genetic Psychology, 166, 385-406.

Gelernter, J., Yu, Y., Weiss, R., Brady, K., Panhuysen, C., Yang, B-Z., et al. (2006). Haplotype spanning TTC12 and ANKK1, flanked by the DRD2 and NCAM1 loci, is strongly associated to nicotine dependence in two distinct American populations. Human Molecular Genetics, 15, 3498-3507.

Giedd, J. N., Blumenthal, J., Jeffries, N. O., Castellanos, F. X., Liu, H., Zijdenbos, A., et al. (1999). Brain development during childhood and adolescence: A longitudinal MRI study. Nature Neuroscience, 2, 861-863.

Gilbert, D. G., Izetelny, A., Radtke, R., Hammersley, J., Rabinovich, N. E., Jameson, T. R., et al. (2005). Dopamine receptor (DRD2) genotype-dependent effects of nicotine on attention and distraction during rapid visual information processing. Nicotine E Tobacco Research, 7, 361-379.

Goldman, P. S., \& Alexander, G. E. (1977, June16). Maturation of prefrontal cortex in the monkey revealed by local reversible cryogenic depression. Nature, 267, 613-615.

Golub, M. S., Slotkin, T. A., Tarantal, A. F., \& Pinkerton, K. E. (2007). Visual recognition memory and auditory brainstem response in infant rhesus monkeys exposed perinatally to environmental tobacco smoke. Brain Research, 1151, 102-106.

Herrmann, M., King, K., \& Weitzman, M. (2008). Prenatal tobacco smoke and postnatal secondhand smoke exposure and child neurodevelopment. Current Opinion in Pediatrics, 20, 184-190.
Hill, A. L., Degnan, K. A., Calkins, S. D., \& Keane, S. P. (2006). Profiles of externalizing behavior problems for boys and girls across preschool: The roles of emotion regulation and inattention. Developmental Psychology, 42, 913-928.

Holmboe, K., Fearon, R. M. P., Csibra, G., Tucker, L., \& Johnson, M. H. (2008). "Freeze-frame": A new infant inhibition task and its relation to frontal cortex tasks in infancy and early childhood. Journal of Experimental Child Psychology, 100, 89-114.

Huijbregts, S. C. J., Séguin, J. R., Zelazo, P. D., Parent, S., Japel, C., \& Tremblay, R. E. (2006). Interrelations between maternal smoking during pregnancy, birth weight, and sociodemographic factors in the prediction of early cognitive abilities. Infant and Child Development, 15, 593-607.

Jacobson, S. W., Chiodo, L. M., Sokol, R. J., \& Jacobson, J. L. (2002). Validity of maternal report of prenatal alcohol, cocaine, and smoking in relation to neurobehavioral outcome. Pediatrics, $109,815-825$.

Jönsson, E. G., Nöthen, M. M., Grünhage, F., Farde, L., Nakashima, Y., Propping, P., \& Sedvall, G. C. (1999). Polymorphisms in the dopamine D2 receptor gene and their relationships to striatal dopamine receptor density of healthy volunteers. Molecular Psychiatry, 4, 290-296.

Kahn, R. S., Khoury, J., Nichols, W. C., \& Lanphear, B. P. (2003). Role of dopamine transporter genotype and maternal prenatal smoking in childhood hyperactive-impulsive, inattentive, and oppositional behaviors. Journal of Pediatrics, 143, 104-110.

Kopp, C. B. (1989). Regulation of distress and negative emotions: A developmental view. Developmental Psychology, 25, 343-354.

Laruelle, M., Gelernter, J., \& Innis, R. B. (1998). D 2 receptor binding potential is not affected by TaqI polymorphism at the $\mathrm{D}_{2}$ receptor gene. Molecular Psychiatry, 3, 261-265.

Lavigne, J. V., Arend, R., Rosenbaum, D., Binns, H. J., Christoffel, K. K., \& Gibbons, R. D. (1998). Psychiatric disorders with onset in the preschool years: I. Stability of diagnoses. Journal of the American Academy of Child and Adolescent Psychiatry, 37, 1246-1254.

Levin, E. D., Wilkerson, A., Jones, J. P., Christopher, N. C., \& Briggs, S. J. (1996). Prenatal nicotine effects on memory in rats: Pharmacological and behavioral challenges. Brain Research: Developmental Brain Research, 97, 207-215.

Lichtensteiger, W., Hefti, F., Felix, D., Huwyler, T., Melamed, E., \&, Schlumpf, M. (1982). Stimulation of nigrostriatal dopamine neurons by nicotine. Neuropharmacology, 21, 963-968.

Linnet, K. M., Dalsgaard, S., Obel, C., Wisborg, K., Henriksen, T. B., Rodriguez, A., et al. (2003). Maternal lifestyle factors in pregnancy risk of attention deficit hyperactivity disorder and associated behaviors: Review of the current evidence. American Journal of Psychiatry, 160, 1028-1040.

Mannuzza, S., Klein, R. G., Bessler, A., Malloy, P., \& LaPadula, M. (1998). Adult psychiatric status of hyperactive boys grown up. American Journal of Psychiatry, 155, 493-498.

Matheny, A. P., Riese, M. L., \& Wilson, R. S. (1985). Rudiments of infant temperament: Newborn to 9 months. Developmental Psychology, 21, 486-494.

McFarland, B., Seidler, F., \& Slotkin, T. (1991). Inhibition of DNA synthesis in neonatal rat brain regions caused by acute nicotine administration. Developmental Brain Research, 58, 223-229.

Miller, D., Villa, K., Hogue, S., \& Sivapathasundaram, D. (2001). Birth and first-year costs for mothers and infants attributable to maternal smoking. Nicotine and Tobacco Research, 3, 25-35.

Miller, E., \& Cohen, J. (2001). An integrative theory of prefrontal cortex function. Annual Reviews of Neuroscience, 24, 167-202. 
Moffitt, T. E. (1993). Adolescence-limited and life-course-persistent antisocial behavior: A developmental taxonomy. Psychological Review, 100, 674-701.

Montague, P. R., Hyman, S. E., \& Cohen, J. D. (2004, October14). Computational roles for dopamine in behavioural control. $\mathrm{Na}$ ture, 431, 760-767.

Munafò, M. R., Clark, T. G., Johnstone, E. C., Murphy, M. F., \& Walton, R. T. (2004). The genetic basis for smoking behavior: A systematic review and meta-analysis. Nicotine \& Tobacco Research, 6, 583-597.

Muneoka, K., Ogawa, T., Kamei, K., Muraoka, S., Tomiyoshi, R., Mimura, Y., et al. (1997). Prenatal nicotine exposure affects the development of the central serotonergic system as well as the dopaminergic system in rat offspring: Involvement of route of drug administration. Developmental Brain Research, 102, $117-126$

Nation, K., Clarke, P., Wright, B., \& Williams, C. (2006). Patterns of reading ability in children with autism spectrum disorder. Journal of Autism and Developmental Disorders, 36, 911-919.

Navarro, H. A., Seidler, F. J., Eylers, J. P., Baker, F. E., Dobbins, S. S., Lappi, S. E., et al. (1989). Effects of prenatal nicotine exposure on development of central and peripheral cholinergic neurotransmitter systems: Evidence for cholinergic trophic influences in developing brain. Journal of Pharmacology and Experimental Therapeutics, 251, 894-900.

Nelson, E., Jodscheit, K., \& Guo, Y. (1999). Maternal passive smoking during pregnancy and fetal developmental toxicity: Part I. Gross morphological effects. Human and Experimental Toxicology, 18, 252-256.

Neuman, R. J., Lobos, E., Reich, W., Henderson, C. A., Sun, L. W., \& Todd, R. D. (2007). Prenatal smoking exposure and dopaminergic genotypes interact to cause a severe ADHD subtype. Biological Psychiatry, 15, 1320-1328.

Neville, M. J., Johnstone, E. C., \& Walton, R. T. (2004). Identification and characterization of ANKK1: A novel kinase gene closely linked to DRD2 on chromosome band 11q23.1. Human Mutation, 23, 540-545.

Nigg, J. T. (2005). Neuropsychologic theory and findings in attention-deficit/hyperactivity disorder: The state of the field and salient challenges for the coming decade. Biological Psychiatry, $57,1424-1435$.

Nigg, J. T., \& Breslau, N. (2007). Prenatal smoking exposure, low birth weight, and disruptive behavior disorders. Journal of the American Academy of Child and Adolescent Psychiatry, 46, 362-369.

Noble, E. P. (2003). D2 dopamine receptor gene in psychiatric and neurologic disorders and its phenotypes. American Journal of Medical Genetics Part B: Neuropsychiatric Genetics, 116, 103-125.

Noble, E. P., Blum, K., Ritchie, T., Montgomery, A., \& Sheridan, P. J. (1991). Allelic association of the D2 dopamine receptor gene with receptor binding characteristics in alcoholism. Archives of General Psychiatry, 48, 648-654.

Noble, K. G., Norman, M. F., \& Farah, M. J. (2005). Neurocognitive correlates of socioeconomic status in kindergarten children. Developmental Science, 8, 74-87.

Noland, J. S., Singer, L. T., Short, E. J., Minnes, S., Arendt, R. E., Kirchner, H. L., et al. (2005). Prenatal drug exposure and selective attention in preschoolers. Neurotoxicology and Teratology, 27, 429-438.

Nyman, E. S., Ogdie, M. N., Loukola, A., Varilo, T., Taanila, A., Hurtig, T., et al. (2007). ADHD candidate gene study in a population-based birth cohort: Association with DBH and DRD2.
Journal of the American Academy of Child and Adolescent Psychiatry, 46, 1614-1621.

Ochsner, K. N., \& Gross, J. J. (2005). The cognitive control of emotion. Trends in Cognitive Sciences, 9, 242-249.

Persico, A. M., Bird, G., Gabbay, F. H., \& Uhl, G. R. (1996). D2 dopamine receptor gene TaqI A1 and B1 restriction fragment length polymorphisms: Enhanced frequencies in psychostimulant-preferring polysubstance abusers. Biological Psychiatry, 40, 776-784.

Pohjalainen, T., Rinne, J. O., Någren, K., Lehikoinen, P., Anttila, K., Syvalahti, E. K. G., et al. (1998). The A1 allele of the human $\mathrm{D}_{2}$ dopamine receptor gene predicts low $\mathrm{D}_{2}$ receptor availability in healthy volunteers. Molecular Psychiatry, 3, 256-260.

Posner, M. I., \& Rothbart, M. K. (2007). Research on attention networks as a model for the integration of psychological science. Annual Review of Psychology, 58, 1-23.

Prevor, M. B., \& Diamond, A. (2005). Color-object interference in young children: A Stroop effect in children $3 \frac{1}{1} 2-6 \frac{1}{2} 2$ years old. Cognitive Development, 20, 256-278.

Reitan, R. M. (1955). The relation of the Trail Making Test to organic brain damage. Journal of Consulting Psychology, 19, 393-394.

Richardson, S. A., \& Tizabi, Y. (1994). Hyperactivity in the offspring of nicotine-treated rats: Role of the mesolimbic and nigrostriatal dopaminergic pathways. Pharmacology, Biochemistry, \& Behavior, 47, 331-337.

Riese, M. L. (1983). Assessment of behavioral patterns in neonates. Infant Behavior and Development, 6, 241-246.

Riese, M. L. (1984). Within-pair differences in newborn twins: Effects of gender and gestational age on behavior. Acta Geneticae Medicae et Gemellogiae, 33, 159-164.

Riese, M. L. (1987). Temperament stability between the neonatal period and 24 months. Developmental Psychology, 23, 216-222.

Riese, M. L. (1989). Maternal alcohol and pentazocine abuse: Neonatal behavior and morphology in an opposite-sex twin pair. Acta Geneticae Medicae et Gemellogiae, 38, 49-56.

Rodríguez-Jiménez, R., Avila, C., Ponce, G., Ibanez, M. I., Rubio, G., Jiménez-Arriero, M. A., et al. (2006). The TaqIA polymorphism linked to the DRD2 gene is related to lower attention and less inhibitory control in alcoholic patients. European Psychiatry, 21, 66-69.

Roesch-Ely, D., Scheffel, H., Weiland, S., Schwaninger, M., Hundemer, H.-P., Kolter, T., et al. (2005). Differential dopaminergic modulation of executive control in healthy subjects. Psychopharmacology, 178, 420-430.

Rothbart, M. K., Derryberry, D., \& Hershey, K. (2000). Stability of temperament in childhood: Laboratory infant assessment to parent report at seven years. In V. J.Molfese \& D. L.Molfese (Eds.), Temperament and personality development across the life span (pp. 85-119). Hillsdale, NJ: Erlbaum.

Ruff, H. A., \& Rothbart, M. K. (1996). Attention in early development: Themes and variations. New York: Oxford University Press.

Scarr, S., \& McCartney, K. (1983). How people make their own environments: A theory of genotype $\rightarrow$ environment effects. Child Development, 54, 424-435.

Sealfon, S. C., \& Olanow, C. W. (2000). Dopamine receptors: From structure to behavior. Trends in Neuroscience, 23, S34-S40.

Spitz, M. R., Shi, H., Yang, F., Hudmon, K. S., Jiang, H., Chamberlain, R. M., et al. (1998). Case-control study of the D2 dopamine receptor gene and smoking status in lung cancer patients. Journal of the National Cancer Institute, 90, 358-363. 
Stins, J. F., van Baal, G. C. M., Polderman, T. J. C., Verhulst, F. C., \& Boomsma, D. I. (2004). Heritability of Stroop and flanker performance in 12-year-old children. BMC Neuroscience, 5, 49.

Szatmari, P., Saigal, S., Rosenbaum, P., Campbell, D., \& King, S. (1990). Psychiatric disorders at five years among children with birthweights < 1000 g: A regional perspective. Developmental Medicine and Child Neurology, 32, 954-962.

Thatcher, R. W. (1994). Psychopathology of early frontal lobe damage: Dependence on cycles of development. Development and Psychopathology, 6, 565-596.

Thompson, J., Thomas, N., Singleton, A., Piggott, M., Lloyd, S., Perry, E. K., et al. (1997). D2 dopamine receptor gene (DRD2) TaqIA polymorphism: Reduced dopamine D2 receptor binding in the human striatum associated with the A1 allele. Pharmacogenetics, 7, 479-484.

U.S. Department of Health and Human Services. (1980). Reducing the health consequences of smoking: 25 years of progress: A report of the Surgeon General(DHHS Publication No. 89-8411). Washington, DC: Author.

Vaglenova, J., Birru, S., Pandiella, N. M., \& Breese, C. R. (2004). An assessment of the long-term developmental and behavioral teratogenicity of prenatal nicotine exposure. Behavioural Brain Research, 150, 159-170.

Wachs, T. D. (2006). The nature, etiology and consequences of individual differences in temperament. In T.LeMonda \& L.Balter (Eds.), Child psychology: A handbook of contemporary issues (2nd ed., pp. 27-52). New York: Garland.

Wakschlag, L., Briggs-Gowan, M., Carter, A., Hill, C., Danis, B., Keenan, K., et al. (2007). A developmental framework for distinguishing disruptive behavior from normative misbehavior in preschool children. Journal of Child Psychology, Psychiatry $\mathcal{E}$ Allied Disciplines, 48, 976-987.

Wakschlag, L. S., Leventhal, B. L., Pine, D. S., Pickett, K. E., \& Carter, A. S. (2006). Elucidating early mechanisms of developmental psychopathology: The case of prenatal smoking and disruptive behavior. Child Development, 77, 893-906.

Wakschlag, L. S., Pickett, K. E., Cook, E., Jr., Benowitz, N. L., \& Leventhal, B. L. (2002). Maternal smoking during pregnancy and severe antisocial behavior in offspring: A review. American Journal of Public Health, 92, 966-974.

Welsh, M. C., Pennington, B. F., \& Groisser, D. B. (1991). A normative-developmental study of executive function: A window on prefrontal function in children. Developmental Neuropsychology, 7, 131-149.

Widom, C. S., \& Brzustowicz, L. M. (2006). MAOA and the "cycle of violence": Childhood abuse and neglect, MAOA genotype, and risk for violent and antisocial behavior. Biological Psychiatry, 60, 684-689.

Willoughby, M., Greenberg, M., Blair, C., \& Stifter, C. (2007). Neurobehavioral consequences of prenatal exposure to smoking at 6 to 8 months of age. Infancy, 12, 273-301.

Wilson, B. J., \& Gottman, J. M. (1996). Attention: The shuttle between emotion and cognition: Risk, resiliency, and physiological bases. In E. M.Hetherington \& E. A.Blechman (Eds.), Stress, coping, and resiliency in children and families (pp. 189-228). Mahwah, NJ: Erlbaum.

Yamagata, S., Takahashi, Y., Kijima, N., Maekawa, H., Ono, Y., \& Ando, J. (2005). Genetic and environmental etiology of effortful control. Twin Research and Human Genetics, 8, 300-306. 